\title{
Cancer risk in the relatives of patients with nasopharyngeal carcinoma-a register-based cohort study in Sweden
}

\author{
Z Liu ${ }^{*, 1}$, F Fang ${ }^{1}$, E T Chang ${ }^{2,3}$ and W Ye ${ }^{1}$
}

${ }^{1}$ Department of Medical Epidemiology and Biostatistics, Karolinska Institutet, Stockholm, Sweden; ${ }^{2}$ Exponent, Inc., Health Sciences Practice, 149 Commonwealth Drive, Menlo Park, CA, USA and ${ }^{3}$ Division of Epidemiology, Department of Health Research and Policy, Stanford University School of Medicine, Stanford, CA, USA

Background: Little is known about cancer susceptibility among relatives of nasopharyngeal carcinoma (NPC) patients in nonendemic areas. We conducted a register-based cohort study to assess the relative risks (RRs) of cancer in families of NPC probands in Sweden.

Methods: By linking 11602616 Swedish-born individuals (defined as 'general population') identified from national censuses to the Swedish Cancer Register and Multi-Generation Register, we identified 9157 relatives (3645 first-degree and 5512 second-degree) of 1211 NPC probands. Cancer incidence during 1961-2009 was ascertained through the Cancer Register. Relative risks of cancer in the relatives of NPC probands, compared with the rest of the general population, were calculated from Poisson regression models.

Results: First-degree relatives had higher risks of NPC $(N=2, R R=4.29,95 \%$ confidence interval $(C l)=1.07$ to 17.17$)$ and cancers of the $\operatorname{larynx}(N=5, R R=2.53,95 \% \mathrm{Cl}=1.05$ to 6.09$)$, prostate $(N=76, R R=1.35,95 \% \mathrm{Cl}=1.07$ to 1.68$)$, and thyroid $(N=10$, $\mathrm{RR}=2.44,95 \% \mathrm{Cl}=1.31$ to 4.53$)$ than the rest of the general population. In addition, a raised risk of cancer of the salivary glands was observed among first-degree relatives of probands with undifferentiated NPC ( $N=2, \mathrm{RR}=6.64,95 \% \mathrm{Cl}=1.66$ to 26.57$)$. In contrast, a decreased risk of colorectal cancer was observed in first- and second-degree relatives $(\mathrm{N}=43, \mathrm{RR}=0.71,95 \% \mathrm{Cl}=0.53$ to 0.96$)$.

Conclusion: The increased risk of NPC and certain other cancers among first-degree relatives may be explained by shared genetic and environmental risk factors, the latter including Epstein-Barr virus infection and smoking or by increased diagnostic intensity.

Familial aggregation of nasopharyngeal carcinoma (NPC) in highincidence areas is well documented (Friborg et al, 2005a; Chang and Adami, 2006; Yu et al, 2009). The involvement of genetic factors in the development of NPC is widely accepted, and the familial risk of NPC is among the highest of any malignancy (Goldgar et al, 1994; Ung et al, 1999; Friborg et al, 2005a). Two studies from high-incidence areas, one in Taiwan and one in southern China, have demonstrated that the increased risk of cancer in NPC families is restricted to NPC (Jia et al, 2004; Yu et al, 2009). By contrast, another study conducted in Greenland, an intermediate-incidence area, showed that relatives of NPC patients were also at increased risks of cancers of the salivary glands and cervix uteri (Friborg et al, 2005a). All of these studies focused on the relatives of probands with undifferentiated NPC, that is, the histopathological subtype that comprises the vast majority of NPC in endemic areas, but the minority in non-endemic areas (Malker et al, 1990; Vaughan et al, 1996; Liu, 1999). Studies of cancer patterns in NPC families in high-incidence areas, however, have been limited by the lack of high-quality register data (Friborg et al, 2005b). 
Outside of high- and intermediate-incidence regions, familial patterns of NPC risk are not well documented. In low-incidence areas, distinct aetiologic factors appear to be involved in the pathogenesis of different histopathological types of NPC (Pathmanathan et al, 1995; Polesel et al, 2011), and aggregation of cancers within NPC families may not be restricted to NPC itself. Understanding the cancer risk among relatives of NPC patients in low-incidence areas can lend insight into the potential shared genetic or environmental risk factors between NPC and other malignancies.

To the best of our knowledge, no previous study has assessed whether cancer risk is increased among relatives of NPC probands in a non-endemic area. The availability of Swedish nation-wide registers, including the Swedish Cancer Register, the Causes of Death Register, and the Multi-Generation Register, provides a unique opportunity to study this research question using highquality population data.

\section{MATERIAL AND METHODS}

Study population. We used data from the Swedish censuses in 1960 (the first national census), 1970, 1980, and 1990 and Swedish Multi-Generation Register to identify the eligible study population. Details about the Swedish Multi-Generation Register have been published (Statistics Sweden, 2009; Ekbom, 2011). In brief, the register includes information on individuals born in 1932 and onward in Sweden, together with their biological or adoptive parents. Familial information is available for nearly all individuals alive in 1991 or deceased before 1968, and for 60\% of the individuals who died between 1968 and 1990. From an initial pool of 13598327 individuals, we excluded those who were not born in Sweden $(N=1963784)$, had a prevalent cancer $(N=27477)$, died $(N=3932)$, or migrated out of Sweden $(N=518)$ before 1961 , leaving a total of 11602616 eligible individuals in the study, defined as the general population.

Established in 1958, the nation-wide Swedish Cancer Register is $>98 \%$ complete (Barlow et al, 2009). Using the Cancer Register, we identified 1811 NPC patients who had not previously been diagnosed with other cancers between 1958 and 2009 and were born in Sweden. Among them, 1213 (67\% of 1811) had retrievable information on at least one first- or second-degree relative born in Sweden in the MultiGeneration Register, and 1211 NPC probands were the first NPC case in their families. Histopathological types of NPC were identified based on WHO/HS/CANC/24.1 (PAD) codes 146 for squamous cell carcinoma and 196 for undifferentiated carcinoma.

First-degree relatives were defined as biological parents, siblings, and children; second-degree relatives were defined as grandparents, grandchildren, uncles, aunts, nieces, nephews, and half-siblings. A total of 9158 relatives for the 1211 NPC probands were identified through the Multi-Generation Register. We excluded 1 relative who had been diagnosed with cancer before 1961, leaving 9157 relatives (3645 first-degree relatives and 5512 second-degree relatives) for the analysis.

All subjects (relatives and the rest of the general population) were followed through record-linkages with the Cancer Register, the Causes of Death Register, and the Emigration Register, by using each individual's unique national personal identification number (Ludvigsson et al, 2009). The number of person-years at risk for each subject was calculated from the date of birth or January 1, 1961, whichever occurred later, until the date of cancer diagnosis, death, emigration, or December 31, 2009, whichever occurred first. This study was approved by the Regional Ethics Review Vetting Board in Stockholm.

Statistical analyses. We used log-linear Poisson regression models to calculate RRs and 95\% confidence intervals (CIs) for overall and site-specific cancer, as the ratio of cancer incidence rates among relatives of NPC probands compared with the rest of the general population. We adjusted for attained age at follow-up (in 5-year intervals), sex, and calendar year at follow-up in all statistical models, and used log-transformed person-years as the offset. We further conducted stratified analyses by the degree of relatedness (first or second) and by histopathological type of NPC (undifferentiated or squamous cell). Statistical analyses were performed using SAS software, version 9.4 (SAS Institute, Inc., Cary, NC, USA). All statistical tests were two-sided, and $P$-values of $<0.05$ were considered to be statistically significant.

\section{RESULTS}

First- and second-degree relatives of NPC probands were followed for a median of 49.0 years and 33.2 years, respectively (Table 1). A bimodal pattern in age at study entry was observed among the first-degree relatives of NPC probands, with a first peak at ages $0-4$ years and a second peak at ages $10-29$ years. The vast majority of second-degree relatives were ages $0-4$ years at study entry. Before the end of 2009, 680 relatives died and 272 emigrated out of Sweden.

In NPC families, 453 cancers were diagnosed among first-degree relatives and 192 cancers among second-degree relatives of probands (Table 2). Overall cancer incidence was not significantly increased among NPC families compared with the rest of the general population ( relative risk $(\mathrm{RR})=1.03,95 \% \mathrm{CI}=0.95$ to $1.11, P=0.50)$. The RR of NPC in first-degree relatives of NPC probands $v s$ the rest of the general population was $4.29(95 \%$ $\mathrm{CI}=1.07$ to 17.17 ), based on the two cases observed. No NPC cases occurred among second-degree relatives of NPC probands.

Risk of buccal cavity cancers other than NPC was marginally significantly increased among first- and second-degree relatives of NPC probands compared with the rest of the general population $(\mathrm{RR}=1.53,95 \% \mathrm{CI}=0.95$ to $2.46, P=0.080$; Table 2 ). This association was especially pronounced for cancer of the salivary glands in first-degree relatives of NPC probands $(N=3, \mathrm{RR}=2.84$, $95 \% \mathrm{CI}=0.92$ to 8.82 ), particularly for probands with undifferentiated NPC $(N=2, \mathrm{RR}=6.64,95 \% \mathrm{CI}=1.66$ to 26.57$)$. Firstdegree relatives were at higher risk of cancers of the larynx $(N=5$, $\mathrm{RR}=2.53,95 \% \mathrm{CI}=1.05$ to 6.09$)$, prostate $(N=76, \mathrm{RR}=1.35$, $95 \% \mathrm{CI}=1.07$ to 1.68$)$, and thyroid $(N=10, \mathrm{RR}=2.44,95 \%$ $\mathrm{CI}=1.31$ to 4.53 ) than the rest of the general population. These associations were stronger among first-degree relatives of probands with differentiated NPC, with RRs of $3.16(95 \% \mathrm{CI}=1.02$ to 9.80$)$, $1.50(95 \%=1.10$ to 2.04$)$, and $2.94(95 \% \mathrm{CI}=1.32$ to 6.56$)$ for cancers of the larynx, prostate, and thyroid, respectively.

Table 1. Characteristics of first- and second-degree relatives of 1211 NPC probands in Sweden, 1961-2009

\begin{tabular}{|c|c|c|}
\hline Characteristics & $\begin{array}{l}\text { First-degree relatives } \\
\qquad(N=3645)\end{array}$ & $\begin{array}{c}\text { Second-degree } \\
\text { relatives }(N=5512)\end{array}$ \\
\hline $\begin{array}{l}\text { Mean age at study } \\
\text { entry, years (s.d.) }\end{array}$ & $15.1(15.3)$ & $3.1(10.2)$ \\
\hline \multicolumn{3}{|c|}{ Age group at entry, no. (\%) } \\
\hline $0-4$ & $1220(33.5)$ & $4910(89.1)$ \\
\hline $5-9$ & $380(10.4)$ & 104 (1.9) \\
\hline $10-29$ & $1538(42.2)$ & $266(4.8)$ \\
\hline $30-49$ & $342(9.4)$ & $160(2.9)$ \\
\hline $50+$ & $165(4.5)$ & $72(1.3)$ \\
\hline $\begin{array}{l}\text { Median duration of } \\
\text { follow-up, years }\end{array}$ & 49.0 & 33.2 \\
\hline $\begin{array}{l}\text { Total no. of person- } \\
\text { years at risk }\end{array}$ & 150902 & 176724 \\
\hline No. of cancer cases & 453 & 192 \\
\hline $\begin{array}{l}\text { Mean age at end of } \\
\text { follow-up, years (s.d.) }\end{array}$ & $56.5(17.0)$ & $35.2(16.5)$ \\
\hline
\end{tabular}


Table 2. Relative risks and $95 \%$ Cls for cancer occurrence in the relatives of NPC probands in Sweden, 1961-2009

\begin{tabular}{|c|c|c|c|c|c|c|}
\hline \multirow[b]{2}{*}{$\begin{array}{l}\text { Cancer site or type (ICD-7 } \\
\text { code) }\end{array}$} & \multicolumn{2}{|c|}{ Overall } & \multicolumn{2}{|c|}{ First-degree relatives } & \multicolumn{2}{|c|}{ Second-degree relatives } \\
\hline & $\begin{array}{c}\text { Cases in NPC } \\
\text { relatives }\end{array}$ & $\mathrm{RR}(95 \% \mathrm{Cl})$ & $\begin{array}{c}\text { Cases in NPC } \\
\text { relatives }\end{array}$ & $\mathrm{RR}(95 \% \mathrm{Cl})$ & $\begin{array}{l}\text { Cases in NPC } \\
\text { relatives }\end{array}$ & $\operatorname{RR}(95 \% \mathrm{Cl})$ \\
\hline All cancers (140-209) & 645 & $1.03(0.95,1.11)$ & 453 & $1.07(0.97,1.17)$ & 192 & $0.94(0.82,1.08)$ \\
\hline NPC (146) & 2 & $2.79(0.70,11.18)$ & 2 & $\begin{array}{c}4.29(1.07,17.17) \\
(P \text { value }=0.040)\end{array}$ & 0 & NA \\
\hline $\begin{array}{l}\text { Buccal cavity, excluding NPC (140- } \\
145,147-148)\end{array}$ & 17 & $1.53(0.95,2.46)$ & 11 & $1.46(0.81,2.64)$ & 6 & $1.66(0.75,3.70)$ \\
\hline Salivary glands (142) & 4 & $2.45(0.92,6.52)$ & 3 & $2.84(0.92,8.82)$ & 1 & $1.72(0.24,12.22)$ \\
\hline Esophagus (150) & 4 & $0.88(0.33,2.35)$ & 3 & $0.94(0.30,2.91)$ & 1 & $0.74(0.10,5.28)$ \\
\hline Stomach (151) & 13 & $0.80(0.46,1.37)$ & 13 & $1.13(0.66,1.95)$ & 0 & NA \\
\hline Colon and rectum $(153,154.0)$ & 43 & $\begin{array}{l}0.71(0.53,0.96) \\
(P \text { value }=0.026)\end{array}$ & 30 & $0.71(0.50,1.02)$ & 13 & $0.72(0.42,1.24)$ \\
\hline Liver cancer (155) & 11 & $0.97(0.54,1.75)$ & 7 & $0.88(0.42,1.84)$ & 4 & $1.18(0.44,3.16)$ \\
\hline Pancreas (157) & 20 & $1.51(0.97,2.34)$ & 13 & $1.40(0.81,2.42)$ & 7 & $1.76(0.84,3.70)$ \\
\hline Larynx (161) & 6 & $2.07(0.93,4.62)$ & 5 & $\begin{array}{l}2.53(1.05,6.09) \\
(P \text { value }=0.038)\end{array}$ & 1 & $1.08(0.15,7.69)$ \\
\hline Lung (162) & 50 & $1.27(0.96,1.67)$ & 35 & $1.29(0.93,1.80)$ & 15 & $1.22(0.73,2.02)$ \\
\hline Breast (170) & 90 & $0.93(0.76,1.15)$ & 70 & $1.15(0.91,1.45)$ & 20 & $\begin{array}{l}0.57(0.37,0.88) \\
(P \text { value }=0.011)\end{array}$ \\
\hline Cervix (171) & 16 & $1.12(0.69,1.84)$ & 11 & $1.31(0.72,2.36)$ & 5 & $0.86(0.36,2.06)$ \\
\hline Endometrium (172) & 13 & $0.71(0.41,1.22)$ & 10 & $0.83(0.45,1.55)$ & 3 & $0.48(0.15,1.47)$ \\
\hline Prostate (177) & 101 & $\begin{array}{l}1.30(1.07,1.58) \\
(P \text { value }=0.008)\end{array}$ & 76 & $\begin{array}{l}1.35(1.07,1.68) \\
(P \text { value }=0.010)\end{array}$ & 25 & $1.18(0.80,1.75)$ \\
\hline Kidney (180) & 13 & $0.78(0.45,1.35)$ & 8 & $0.71(0.36,1.43)$ & 5 & $0.93(0.39,2.24)$ \\
\hline Bladder (181.0) & 25 & $1.06(0.72,1.57)$ & 15 & $0.91(0.55,1.50)$ & 10 & $1.43(0.77,2.66)$ \\
\hline Skin cancer, melanoma (190) & 27 & $0.86(0.59,1.26)$ & 18 & $0.98(0.62,1.55)$ & 9 & $0.70(0.36,1.34)$ \\
\hline Skin cancer, non-melanoma (191) & 23 & $1.20(0.80,1.81)$ & 18 & $1.30(0.82,2.06)$ & 5 & $0.95(0.39,2.27)$ \\
\hline Brain (193) & 25 & $0.84(0.57,1.25)$ & 14 & $0.83(0.49,1.40)$ & 11 & $0.87(0.48,1.57)$ \\
\hline Thyroid (194) & 14 & $\begin{array}{l}2.04(1.21,3.44) \\
(P \text { value }=0.008)\end{array}$ & 10 & $\begin{array}{l}2.44(1.31,4.53) \\
(P \text { value }=0.005)\end{array}$ & 4 & $1.44(0.54,3.84)$ \\
\hline Lymphoma (200-202) & 26 & $0.88(0.59,1.32)$ & 19 & $0.98(0.61,1.57)$ & 7 & $0.72(0.34,1.50)$ \\
\hline Hodgkin lymphoma (201) & 3 & $0.51(0.17,1.59)$ & 0 & NA & 3 & $1.16(0.37,3.59)$ \\
\hline Non-Hodgkin lymphoma $(200,202)$ & 21 & $1.04(0.68,1.60)$ & 17 & $1.28(0.79,2.05)$ & 4 & $0.58(0.22,1.56)$ \\
\hline Multiple myeloma (203) & 10 & $1.39(0.75,2.58)$ & 8 & $1.59(0.79,3.18)$ & 2 & $0.92(0.23,3.67)$ \\
\hline Leukaemia (204-207) & 22 & $1.19(0.78,1.81)$ & 10 & $0.85(0.46,1.59)$ & 12 & $\begin{array}{l}1.78(1.01,3.13) \\
(P \text { value }=0.046)\end{array}$ \\
\hline
\end{tabular}

By contrast, the RRs for first-degree relatives of undifferentiated NPC probands were $1.76(95 \% \mathrm{CI}=0.25$ to 12.51$), 1.02(95 \%$ $\mathrm{CI}=0.63$ to 1.64$)$, and $1.70(95 \% \mathrm{CI}=0.43$ to 6.81$)$ for cancers of the larynx, prostate, and thyroid, respectively.

Colorectal cancer risk was significantly decreased among firstand second-degree relatives of NPC probands compared with the rest of the general population $(N=43, \mathrm{RR}=0.71,95 \% \mathrm{CI}=0.53$ to $0.96)$, with no substantial difference in the $\mathrm{RR}$ by degree of relatedness (Table 2 ).

Risk of other EBV-associated cancers, including Hodgkin lymphoma, non-Hodgkin lymphoma, and possibly gastric cancer, was not significantly different among relatives of NPC probands compared with the rest of general population (Table 2).

\section{DISCUSSION}

To the best of our knowledge, this is the first cohort study to evaluate cancer risk among relatives of NPC probands in a low-risk population. The present study shows an increased risk of NPC among first-degree relatives of NPC probands in a non-endemic geographic area. This study also shows an increased risk of salivary gland cancer among first-degree relatives of probands with undifferentiated NPC, a result that is consistent with findings from one study in Greenland (Friborg et al, 2005a). However, we did not detect a significantly increased risk of cervical cancer in NPC families, as was observed in the Greenland study. The observed increase in risk of salivary gland cancer among relatives of probands with undifferentiated NPC may be due in part to shared genetic background and/or environmental risk factors, the latter including EBV infection and diet (Saemundsen et al, 1982; Leung et al, 1995; Shebl et al, 2010).

Elevated risks of cancers of the larynx, prostate, and thyroid among relatives of NPC probands, particularly those with differentiated NPC, have not previously been reported. The observed increase in laryngeal cancer risk among first-degree relatives of NPC probands may be due to shared environmental risk factors, such as tobacco smoking and alcohol consumption (Franceschi et al, 1990; Gronbaek et al, 1998). This explanation is supported by evidence that smoking and alcohol drinking are more 
consistently associated with risk of differentiated than undifferentiated NPC (Vaughan et al, 1996; Hsu et al, 2011; Polesel et al, 2011). There is no evidence to date linking prostate cancer and NPC. The cumulative uptake of PSA testing in men aged 55 to 69 years in Sweden increased from 0\% in 1997 to 56\% in 2007 (Jonsson et al, 2011). Therefore, we conducted a secondary analysis stratified by calendar period of follow-up: before 1997 vs 1997 and thereafter. Compared with the rest of the general population, the RRs of prostate cancer among first-degree relatives of NPC probands before and after 1997 were $0.77(95 \% \mathrm{CI}=0.47$ to 1.28$)$ and 1.60 ( $95 \% \mathrm{CI}=1.25$ to 2.06 ), respectively. Therefore, the observed increase in prostate cancer risk among first-degree relatives of NPC probands may be due to increased diagnostic intensity (including prostate cancer screening and diagnostic workup) among relatives of NPC probands. The increased risk of thyroid cancer in NPC families could be due to a shared aetiologic association with EBV infection, as suggested by a small case series of thyroid carcinomas in which EBV was universally expressed (Shimakage et al, 2003). Alternatively, increased diagnostic intensity may also partly explain the observed higher risk of thyroid cancer (Welch and Black, 2010). A chance finding cannot be ruled out.

The observed decrease in the risk of colorectal cancer among relatives of NPC probands in our study is consistent with results from the studies in Taiwan and Greenland (Friborg et al, 2005a; Yu et al, 2009). Notably, the risk of colorectal cancer following primary diagnosis of NPC is also lower than expected (Scelo et al, 2007; Chen et al, 2008). The underlying reasons for this finding remain to be elucidated, and such knowledge may similarly shed light on the aetiology and prevention of NPC.

Risk of another EBV-associated cancer, Hodgkin lymphoma, which occurs at a relatively high incidence rate in Sweden (Grufferman and Delzell, 1984; Chang et al, 2004), tended to be lower in relatives of NPC probands than in the rest of the general population. Although both Hodgkin lymphoma and NPC are aetiologically associated with EBV, the patterns of risk factors diverge between the two malignancies. For example, Hodgkin lymphoma occurs more frequently in Europe and North America and among individuals of Caucasian descent, whereas NPC is relatively common in Southeast Asia and among individuals of southern Chinese descent (Ferlay et al, 2013; Forman et al, 2013). A history of infectious mononucleosis, which is caused by relatively late primary infection with EBV, is associated with an increased risk of Hodgkin lymphoma, whereas it may be inversely associated with NPC risk (Vaughan et al, 1996; Hjalgrim et al, 2000, 2007). Different tissues (i.e., epithelium $v s$ lymphoid tissue) may be more susceptible to different EBV strains, and may be infected with EBV through different mechanisms. Although the small number of Hodgkin lymphoma cases among relatives of NPC probands observed in our study precludes firm conclusions about whether Hodgkin lymphoma risk is indeed lower than expected in NPC families, such a finding seemed to be consistent with existing knowledge of the epidemiology of the two malignancies.

Human leukocyte antigen (HLA) genes have shown the most consistent evidence for associations with NPC risk, although it is unclear whether these associations are due to a direct causal relation (Hildesheim et al, 2002; Bei et al, 2010). The development of other malignancies, including thyroid (Knoll et al, 1997) and cervical cancers (Madeleine et al, 2008), may also be mediated by certain HLA alleles. Thus, HLA-related susceptibility might underlie familial risks of NPC and other cancers, and this area warrants further investigation.

Strengths of our study include its population-based design, the use of high-quality Swedish registers, and the ability to reliably identify first- and second-degree relatives using the Multi-Generation Register. However, there are several limitations of the present study. First, the lack of family information for
598 otherwise eligible NPC cases $(33 \%$ of 1811) in the Multi-Generation Register may affect the generalisability of the present study. Given that a primary reason for missing data is death, and that cancer is one of the leading causes of death in Sweden, we believe these individuals were at a higher risk of cancer than those with family information available in the MultiGeneration Register. Therefore, it is likely that the excess risk of cancers in relatives of NPC cases was underestimated in the present study. Second, we lacked information on environmental exposures and genetic risk factors, thereby preventing the investigation of potential shared risk factors. Third, the number of cancers observed in relatives was modest for most sites. The limited numbers were due in part to the relatively young age of the relatives, which was restricted to subjects enrolled after 1961 and diagnosed with cancer by 2009. Finally, the observed elevated risk in first-degree relatives of patients with NPC was based on only two cases. Although we determined that the parents of one of these cases were also born in Sweden, we cannot rule out the possibility that one or both of the parents of the other NPC case migrated from a country with high NPC incidence, where familial aggregation of NPC is relatively common. However, after excluding the family of the NPC probands without parents' information, we could still observe an increased risk of NPC among the first-degree relatives $(\mathrm{RR}=3.85,95 \% \mathrm{CI}=0.54$ to 27.38) of NPC probands, compared with the rest of the general population. Interpretation of these findings should be cautious given the small number of cancer cases observed among relatives of NPC probands.

In conclusion, relatives of NPC probands in the low-incidence population of Sweden are at increased risk of not only NPC, but also certain other cancers. This increased risk is especially pronounced among relatives of probands with differentiated NPC, the histopathological type that is most common in nonendemic areas. Shared environmental risk factors such as EBV infection and smoking may explain the observed associations, although shared genetic susceptibility, increased diagnostic intensity, and chance cannot be ruled out.

\section{ACKNOWLEDGEMENTS}

The present study was supported by a grant from the Swedish Research Council (SIMSAM Grant No. 80748301). ZL was supported by a scholarship from the Karolinska Institutet (KID) and FF was supported by the Swedish Society for Medical Research (SSMF) and the Karolinska Institutet. We certify that we have not entered into any agreement that could interfere with their access to the data on the research, nor upon their ability to analyse the data independently, to prepare manuscripts, and to publish them.

\section{REFERENCES}

Barlow L, Westergren K, Holmberg L, Talback M (2009) The completeness of the Swedish Cancer Register: a sample survey for year 1998. Acta Oncologica 48(1): 27-33.

Bei JX, Li Y, Jia WH, Feng BJ, Zhou G, Chen LZ, Feng QS, Low HQ, Zhang H, He F, Tai ES, Kang T, Liu ET, Liu J, Zeng YX (2010) A genome-wide association study of nasopharyngeal carcinoma identifies three new susceptibility loci. Nat Genet 42(7): 599-603.

Chang ET, Adami HO (2006) The enigmatic epidemiology of nasopharyngeal carcinoma. Cancer Epidemiol Biomarkers Prev 15(10): 1765-1777.

Chang ET, Montgomery SM, Richiardi L, Ehlin A, Ekbom A, Lambe M (2004) Number of siblings and risk of Hodgkin's lymphoma. Cancer Epidemiol Biomarkers Prev 13(7): 1236-1243.

Chen MC, Feng IJ, Lu CH, Chen CC, Lin JT, Huang SH, Lee KD (2008) The incidence and risk of second primary cancers in patients with 
nasopharyngeal carcinoma: a population-based study in Taiwan over a 25-year period (1979-2003). Ann Oncol 19(6): 1180-1186.

Ekbom A (2011) The Swedish Multi-generation Register. Methods Mol Biol 675: 215-220.

Ferlay J, Soerjomataram I, Ervik M, Dikshit R, Eser S, Mathers C, Rebelo M, Parkin DM, Forman D, Bray F (2013) GLOBOCAN 2012 v1.0, Cancer Incidence and Mortality Worldwide: IARC CancerBase No. 11 [Internet]. International Agency for Research on Cancer: Lyon, France, Available from http://globocan.iarc.fr.

Forman D, Bray F, Brewster DH, Mbalawa CG, Kohler B, Piñeros M, Steliarova-Foucher E, Swaminathan R, Ferlay J (eds) (2013) Cancer Incidence in Five Continents Vol. X, (electronic version) IARC: Lyon.

Franceschi S, Talamini R, Barra S, Baron AE, Negri E, Bidoli E, Serraino D, La Vecchia C (1990) Smoking and drinking in relation to cancers of the oral cavity, pharynx, larynx, and oesophagus in northern Italy. Cancer Res 50(20): 6502-6507.

Friborg J, Wohlfahrt J, Koch A, Storm H, Olsen OR, Melbye M (2005a) Cancer susceptibility in nasopharyngeal carcinoma families-a populationbased cohort study. Cancer Res 65(18): 8567-8572.

Friborg J, Wohlfahrt J, Melbye M (2005b) Familial risk and clustering of nasopharyngeal carcinoma in Guangdong, China. Cancer 103(1): 211 author reply 211-2.

Goldgar DE, Easton DF, Cannon-Albright LA, Skolnick MH (1994) Systematic population-based assessment of cancer risk in first-degree relatives of cancer probands. J Natl Cancer Inst 86(21): 1600-1608.

Gronbaek M, Becker U, Johansen D, Tonnesen H, Jensen G, Sorensen TI (1998) Population based cohort study of the association between alcohol intake and cancer of the upper digestive tract. BMJ 317(7162): 844-847.

Grufferman S, Delzell E (1984) Epidemiology of Hodgkin's disease. Epidemiol Rev 6: 76-106.

Hildesheim A, Apple RJ, Chen CJ, Wang SS, Cheng YJ, Klitz W, Mack SJ, Chen IH, Hsu MM, Yang CS, Brinton LA, Levine PH, Erlich HA (2002) Association of HLA class I and II alleles and extended haplotypes with nasopharyngeal carcinoma in Taiwan. J Natl Cancer Inst 94(23): 1780-1789.

Hjalgrim H, Askling J, Sorensen P, Madsen M, Rosdahl N, Storm HH, Hamilton-Dutoit S, Eriksen LS, Frisch M, Ekbom A, Melbye M (2000) Risk of Hodgkin's disease and other cancers after infectious mononucleosis. J Natl Cancer Inst 92(18): 1522-1528.

Hjalgrim H, Smedby KE, Rostgaard K, Molin D, Hamilton-Dutoit S, Chang ET, Ralfkiaer E, Sundstrom C, Adami HO, Glimelius B, Melbye M (2007) Infectious mononucleosis, childhood social environment, and risk of Hodgkin lymphoma. Cancer Res 67(5): 2382-2388.

Hsu WL, Yu KJ, Chien YC, Chiang CJ, Cheng YJ, Chen JY, Liu MY, Chou SP, You SL, Hsu MM, Lou PJ, Wang CP, Hong JH, Leu YS, Tsai MH, Su MC Tsai ST, Chao WY, Ger LP, Chen PR, Yang CS, Hildesheim A, Diehl SR, Chen CJ (2011) Familial tendency and risk of nasopharyngeal carcinoma in taiwan: effects of covariates on risk. Am J Epidemiol 173(3): 292-299.

Jia WH, Feng BJ, Xu ZL, Zhang XS, Huang P, Huang LX, Yu XJ, Feng QS, Yao MH, Shugart YY, Zeng YX (2004) Familial risk and clustering of nasopharyngeal carcinoma in Guangdong, China. Cancer 101(2): 363-369.

Jonsson H, Holmstrom B, Duffy SW, Stattin P (2011) Uptake of prostatespecific antigen testing for early prostate cancer detection in Sweden. Int J Cancer 129(8): 1881-1888.

Knoll MR, Schwab M, Oestreich K, Rumstadt B, Hagmuller E (1997) HLA class II expression in well differentiated thyroid carcinoma: correlation with clinicopathological features. J Exp Clin Cancer Res 16(2): 177-182.
Leung SY, Chung LP, Yuen ST, Ho CM, Wong MP, Chan SY (1995) Lymphoepithelial carcinoma of the salivary gland: in situ detection of Epstein-Barr virus. J Clin Pathol 48(11): 1022-1027.

Liu T (1999) Issues in the management of nasopharyngeal carcinoma. Crit Rev Oncol Hematol 31(1): 55-69.

Ludvigsson JF, Otterblad-Olausson P, Pettersson BU, Ekbom A (2009) The Swedish personal identity number: possibilities and pitfalls in healthcare and medical research. Eur J Epidemiol 24(11): 659-667.

Madeleine MM, Johnson LG, Smith AG, Hansen JA, Nisperos BB, Li S, Zhao LP, Daling JR, Schwartz SM, Galloway DA (2008) Compre hensive analysis of HLA-A, HLA-B, HLA-C, HLA-DRB1, and HLA-DQB1 loci and squamous cell cervical cancer risk. Cancer Res 68(9): 3532-3539.

Malker HS, McLaughlin JK, Weiner JA, Silverman DT, Blot WJ, Ericsson JL, Fraumeni JF Jr (1990) Occupational risk factors for nasopharyngeal cancer in Sweden. Br J Ind Med 47(3): 213-214.

Pathmanathan R, Prasad U, Chandrika G, Sadler R, Flynn K, Raab-Traub N (1995) Undifferentiated, nonkeratinizing, and squamous cell carcinoma of the nasopharynx. Variants of Epstein-Barr virus-infected neoplasia. Am J Pathol 146(6): 1355-1367.

Polesel J, Franceschi S, Talamini R, Negri E, Barzan L, Montella M, Libra M, Vaccher E, Franchin G, La Vecchia C, Serraino D (2011) Tobacco smoking, alcohol drinking, and the risk of different histological types of nasopharyngeal cancer in a low-risk population. Oral Oncol 47(6): 541-545.

Saemundsen AK, Albeck H, Hansen JP, Nielsen NH, Anvret M, Henle W, Henle G, Thomsen KA, Kristensen HK, Klein G (1982) Epstein-Barr virus in nasopharyngeal and salivary gland carcinomas of Greenland Eskimoes. Br J Cancer 46(5): 721-728.

Scelo G, Boffetta P, Corbex M, Chia KS, Hemminki K, Friis S, Pukkala E, Weiderpass E, McBride ML, Tracey E, Brewster DH, Pompe-Kirn V, Kliewer EV, Tonita JM, Martos C, Jonasson JG, Brennan P (2007) Second primary cancers in patients with nasopharyngeal carcinoma: a pooled analysis of 13 cancer registries. Cancer Causes Control 18(3): 269-278.

Shebl FM, Bhatia K, Engels EA (2010) Salivary gland and nasopharyngeal cancers in individuals with acquired immunodeficiency syndrome in United States. Int J Cancer 126(10): 2503-2508.

Shimakage M, Kawahara K, Sasagawa T, Inoue H, Yutsudo M, Yoshida A, Yanoma S (2003) Expression of Epstein-Barr virus in thyroid carcinoma correlates with tumor progression. Hum Pathol 34(11): 1170-1177.

Statitics Sweden (2009) Multi-Generation Register, 2009. A description of contents and quality. Statistics Sweden: Örebro, Sweden.

Ung A, Chen CJ, Levine PH, Cheng YJ, Brinton LA, Chen IH, Goldstein AM, Hsu MM, Chhabra SK, Chen JY, Apple RJ, Yang CS, Hildesheim A (1999) Familial and sporadic cases of nasopharyngeal carcinoma in Taiwan. Anticancer Res 19(1B): 661-665.

Vaughan TL, Shapiro JA, Burt RD, Swanson GM, Berwick M, Lynch CF, Lyon JL (1996) Nasopharyngeal cancer in a low-risk population: defining risk factors by histological type. Cancer Epidemiol Biomarkers Prev 5(8): 587-593.

Welch HG, Black WC (2010) Overdiagnosis in cancer. J Natl Cancer Inst 102(9): 605-613.

Yu KJ, Hsu WL, Chiang CJ, Cheng YJ, Pfeiffer RM, Diehl SR, Goldstein AM, Gravitt PE, Chen CJ, Hildesheim A (2009) Cancer patterns in nasopharyngeal carcinoma multiplex families in Taiwan. Int $J$ Cancer 124(7): 1622-1625. 